\title{
Stres dan Strategi Daya Tindak dalam kalangan Guru Luar Bandar di Sarawak Sewaktu PdPR
}

\section{(Stress and Coping Strategies Among Rural Area Teachers in Sarawak During PdPR)}

\author{
Nurr Azreen binti Abdul Karim¹ ${ }^{\mathbf{*}}$, Ruslin Amir², Salleh Amat ${ }^{\mathbf{3}}$ \\ 1Fakulti Pendidikan, Universiti Kebangsaan Malaysia (UKM), 43600, Bangi, Selangor, Malaysia. \\ Email: nurrazreen193@gmail.com \\ 2Fakulti Pendidikan, Universiti Kebangsaan Malaysia (UKM), 43600, Bangi, Selangor, Malaysia. \\ Email: ruslin.1959@gmail.com \\ 3Fakulti Pendidikan, Universiti Kebangsaan Malaysia (UKM), 43600, Bangi, Selangor, Malaysia. \\ Email: sallehamat@gmail.com
}

\section{CORRESPONDING AUTHOR (*): \\ Nurr Azreen binti Abdul Karim (nurrazreen193@gmail.com)}

\section{KATA KUNCI:}

Stres guru

Strategi daya tindak

Pengajaran dan Pembelajaran di Rumah (PdPR)

\section{KEYWORDS:}

Stress among teachers

Coping strategies

Home-based learning

\section{CITATION:}

Nurr Azreen binti Abdul Karim, Ruslin Amir, \& Salleh Amat. (2022). Stres dan Strategi Daya Tindak Dalam Kalangan Guru Luar Bandar di Sarawak Sewaktu PdPR. Malaysian Journal of Social Sciences and Humanities (MJSSH), $x(\mathrm{x}), \mathrm{e} 001296$.

https://doi.org/10.47405/mjssh.v7i2.1296

\begin{abstract}
ABSTRAK
Kajian ini bertujuan untuk melihat tahap stres dalam kalangan guru dan strategi daya tindak yang digunakan oleh guru untuk mengurangkan stres sewaktu PdPR. Kajian ini melibatkan 102 orang responden dari sekolah-sekolah luar bandar di daerah Sri Aman, Sarawak. Kajian ini berbentuk tinjauan dengan menggunakan kaedah kuantitatif melalui edaran borang soal selidik secara atas talian. Analisis data secara deskriptif dan inferensi dilakukan dengan menggunakan perisian Statistical Package for the Social Science (SPSS) versi 26. Dapatan kajian menunjukkan tahap stres dalam kalangan guru luar bandar di Sarawak secara keseluruhannya berada pada tahap yang tinggi $(\mathrm{min}=4.09$, s.p. $=0.60)$ manakala tahap strategi daya tindak secara keseluruhannya berada pada tahap yang rendah $(\mathrm{min}=1.97$, s.p. = 0.31). Dapatan kajian ini dijangka dapat memberikan rujukan kepada pelaksana untuk melihat tahap stres guru sewaktu pelaksanaan PdPR dan strategi daya tindak yang boleh digunakan untuk mengurangkan stres tersebut. Kesimpulannya, guru haruslah bijak mengenal pasti dan mengendalikan stres sewaktu tempoh pelaksanaan PdPR ini bagi memastikan keberkesanan pelaksanaan PdPR dan untuk menjamin kesejahteraan mental guru itu sendiri.
\end{abstract}

\section{ABSTRACT}

The aim of this study is to look at the level of stress among teachers and coping strategies by teachers to reduce stress during PdPR. This study involved 102 respondents from rural schools in the district of Sri Aman, Sarawak. This study is a form of survey using quantitative methods through the distribution of online questionnaires. Descriptive and inferential data analysis was analyzed using Statistical Package for the Social Science (SPSS) version 26. The findings showed that the level of stress among rural teachers in Sarawak as a whole was at a high level (mean $=4.09$, s.d. $=$ 
0.31). The findings of this study are expected to provide reference for the authorities to see the level of stress among the teachers during the implementation of PdPR and coping strategies that can be used to reduce such stress. In conclusion, teachers should be wise by identify and manage their stress during PdPR to ensure the effectiveness of PdPR itself and also to ensure the well-being of mental health among the teachers.

Sumbangan/Keaslian: Kajian ini dapat menyumbang kepada literatur sedia ada bagi pelaksanaan PdPR sewaktu musim pandemik. Selain itu, kajian ini dapat dijadikan panduan dan rujukan kepada para guru dalam mengenal pasti tahap stres dan seterusnya memilih strategi daya tindak yang bersesuaian dalam menangani stres tersebut.

\section{Pengenalan}

Pelan Induk Pembangunan Pendidikan (2013-2025) mempunyai tiga gelombang transformasi yang melibatkan semua pihak berkepentingan iaitu kepada murid, guru, pemimpin sekolah, pegawai kementerian, ibu bapa serta pihak komuniti dan swasta (Pelan Induk Pembangunan Pendidikan, 2013). Melalui pelan ini juga, setiap murid akan mendapat manfaat yang signifikan terhadap perkembangan pendidikan melalui akses yang menyeluruh bagi mencapai potensi diri dan seterusnya mempersiapkan diri bagi kehidupan masa hadapan.

Secara lazimnya, penyaluran ilmu dilihat sebagai proses bersemuka di mana guru harus berada di dalam kelas bersama murid-murid. Peranan guru dilihat sebagai pemudahcara dalam menyampaikan isi kandungan pembelajaran dengan menggunakan strategi berpusatkan murid dan bahan pembelajaran. Namun umum mengetahui pandemik Covid-19 yang melanda dunia secara tidak langsung telah memberikan impak kepada sistem pendidikan negara kita di Malaysia. Maka, pihak Kementerian Pendidikan Malaysia (KPM) telah menetapkan pelaksanaan Pengajaran dan Pembelajaran di Rumah (PdPR) sebagai alternatif kepada akses pembelajaran norma baharu dan bagi memastikan proses pengajaran dan pembelajaran tetap boleh dijalankan secara optimum sepertimana yang terkandung dalam Manual Pengajaran dan Pembelajaran di Rumah Versi 2 (Kementerian Pendidikan Malaysia, 2021).

Prinsip asas kepada pelaksanaan PdPR haruslah mengambil kira tiada murid tercicir dalam pembelajaran, asas pembelajaran dipenuhi dan kesejahteraan sosioemosi murid diutamakan. Manakala, pelaksanaan PdPR boleh dilaksanakan dengan menggunakan pendekatan secara dalam talian atau luar talian atau secara luar kawasan sekolah (offsite). Kajian ini bertujuan untuk melihat stres dan strategi daya tindak dalam kalangan guru luar bandar di Sarawak sewaktu pelaksanaan Pengajaran dan Pembelajaran di Rumah (PdPR).

\section{Sorotan Literatur}

Menurut tafsiran Medline Medical Encylopedia (2020), stres adalah ketegangan emosi yang disebabkan oleh peristiwa yang berlaku dalam kehidupan atau fikiran seseorang yang menyebabkan rasa kecewa, marah atau gementar. 
Stres yang berlaku dalam kalangan guru pada masa kini, bukanlah sesuatu yang asing dan harus dipandang ringan. Pengenalan kepada kurikulum baharu dan pembelajaran abad ke-21 membuatkan guru harus lebih komited dan proaktif dalam menjalankan tugasan harian sebagai seorang pendidik. Dalam mendepani perubahan ini, bebanan kerja akan semakin bertambah sehingga menyebabkan tekanan. Menurut Mohamad Saiful dan Wan Shahrazad (2020) tugas guru pada masa kini bukan sahaja menyebarkan ilmu pengetahuan, bahkan guru berperanan sebagai seorang perancang, pengurus, fasilitator dan contoh teladan kepada komuniti. Tuntutan perubahan dan cabaran yang dihadapi telah mengakibatkan bebanan kepada guru yang akhirnya mendorong kepada tekanan kerja yang semakin tinggi.

Selain daripada itu, perubahan dan kesediaan guru dalam berhadapan pengurusan pengajaran dan pembelajaran (PdP) sewaktu musim pandemik Covid-19 pada masa kini juga secara tidak langsung menyebabkan guru-guru berasa tertekan. Ini kerana para guru harus memastikan sesi PdP harus dilaksanakan dengan apa cara sekalipun, sama ada menggunakan platform atas talian (online) mahupun secara edaran modul (offline). Ini telah disokong oleh Sokal et al. (2020) yang menyatakan bahawa peralihan kaedah pembelajaran tradisional kepada pembelajaran dalam talian secara sepenuhnya telah mengakibatkan para guru berusaha mempersiapkan diri dalam tempoh masa yang singkat dalam menjalankan pengajaran jarak jauh (PJJ). Guru berhadapan dengan cabaran dalam penyesuaian meningkatkan pengetahuan dan kompetensi mereka terhadap penggunaan peralatan elektronik dan aplikasi pengajaran yang lebih terkini (Syahiza \& Fariza, 2019).

Norma baharu yang memerlukan guru bertugas dari rumah secara tidak langsung telah menyebabkan rutin kerja guru turut berubah, apabila harus mengendalikan kerja rumah dan ahli keluarga di samping meneruskan kerja hakiki. Menurut Habib dan Syed (2016), kepelbagaian dimensi kerja seorang guru harus difahami agar guru merasa sokongan dan termotivasi dalam melaksanakan tugas sebagai seorang guru dengan sewajarnya. Sewaktu pandemik Covid-19, antara yang perkara yang menyebabkan tekanan kepada para guru adalah kurang berkemahiran dalam teknologi maklumat dan kekurangan peralatan teknologi untuk menjalankan sesi pengajaran, beban kerja, sokongan sosial serta konflik keluarga (Amri et al., 2020).

Seterusnya, dalam konteks kajian ini, strategi daya tindak adalah pemilihan cara untuk guru berhadapan dan mengendalikan stres yang dihadapi sewaktu pelaksanaan PdPR. Strategi daya tindak didefinisikan sebagai usaha yang diambil oleh seseorang individu bagi mengurangkan tekanan yang dihadapi dengan mengubah keadaan emosi atau menyingkirkan sumber-sumber yang menjadi punca tekanan (Lazarus, 1993). Menurut Izazol (2019), daya tindak ditafsirkan sebagai usaha-usaha menyelesaikan masalah dengan menggunakan pemikiran yang rasional dan tingkah laku yang bersesuaian. Melalui pemilihan strategi daya tindak yang bersesuaian oleh para guru dalam mengendalikan tekanan mampu memberikan impak yang berlainan terhadap diri sendiri, sama ada impak yang positif seperti mengurangkan tekanan kerja dan boleh menenangkan emosi guru (MacIntyre et al., 2020)

Kajian-kajian lepas lebih banyak tertumpu kepada stres dalam kalangan guru disebabkan perubahan kurikulum dan beban tugas di luar musim pandemik. Namun demikian, wabak pandemik Covid-19 yang melanda seluruh dunia telah memberikan cabaran yang berbeza kepada seluruh aspek kehidupan manusia. Oleh itu, pengkaji menjalankan kajian ini untuk melihat tahap stres dan strategi daya tindak dalam kalangan guru luar bandar di Sarawak 
setelah pelaksanaan PdPR yang turut memberikan cabaran berbeza kepada aspek profesionalisme keguruan.

\section{Metod Kajian}

\subsection{Reka Bentuk Kajian}

Kajian ini menggunakan reka bentuk kajian tinjauan melalui pendekatan kuantitatif. Tinjauan soal selidik kajian ini diedarkan dalam bentuk atas talian (google form) dengan menggunakan kaedah list-based sampling frame di mana pengkaji mengenal pasti sekolah yang berada dalam kategori luar bandar daripada keseluruhan jumlah sekolah rendah yang ada di daerah Sri Aman, Sarawak.

\subsection{Populasi dan Persampelan}

Populasi dalam kajian ini adalah guru-guru sekolah rendah luar bandar di daerah Sri Aman. Melalui kaedah list-based sampling frame, jumlah responden yang terlibat dalam kajian ini adalah seramai 102 orang iaitu 43 orang guru lelaki dan 59 orang guru perempuan. Data yang diperoleh dianalisis menggunakan Statistical Package for the Social Science (SPSS) Versi 26.

\subsection{Instrumen Kajian}

Instrumen yang digunakan dalam kajian ini adalah menggunakan borang soal selidik atas talian (google forms) yang terbahagi kepada tiga bahagian. Bahagian A adalah mengandungi item soalan berkaitan demografi responden seperti jantina, umur dan pengalaman mengajar. Manakala Bahagian B pula mengandungi 12 item soalan yang diadaptasi daripada soal selidik Job Related Tension Index untuk mengukur dimensi stres. Item pada Bahagian B ini merupakan soal selidik yang berbentuk skala likert lima mata. Pilihan dalam bahagian ini bermula dari "amat setuju" (1), "setuju" (2), diikuti dengan "tidak pasti" (3), "tidak setuju" (4) dan pilihan "amat tidak setuju" (5). Seterusnya, item pada Bahagian C pula mengandungi 16 daripada 22 soalan Stress Coping Inventory yang diadaptasi dan disesuaikan dalam konteks keguruan. Item pada bahagian ini adalah untuk menilai strategi daya tindak yang merangkumi skala kesihatan (wellness scale), skala pemikiran (thought scale), skala daya tindak aktif (active coping scale), skala kemudahan sosial (social ease scale), skala pengurangan stres (tension reduction scale) dan skala kerohanian (spiritual scale).

\subsection{Kesahan dan Kebolehpercayaan}

Menurut Mohd Majid (1990), kesahan secara umumnya merujuk kepada sejauh mana sesuatu instrumen kajian itu mengukur apa yang ingin diukur. Pekali Alpha Cronbach telah digunakan oleh pengkaji untuk menguji kebolehpercayaan soal selidik. Nilai kebolehpercayaan bagi konstruk stres yang diperoleh daripada ujian Alpha Cronbach adalah .868, bermaksud item-item yang digunakan untuk mengukur tahap stres adalah baik dan boleh diterima Manakala, nilai kebolehpercayaan bagi konstruk strategi daya tindak yang diperoleh daripada ujian Alpha Cronbach adalah .683, bermaksud item-item yang digunakan untuk mengukur strategi daya tindak adalah boleh diterima. 


\subsection{Pengumpulan dan Pengukuran Data}

Borang soal selidik telah diberikan secara atas talian melalui pautan google forms kepada pihak pentadbir sekolah untuk diedarkan kepada guru-guru di sekolah masing-masing. Pengkaji kemudiannya mengeksport data ke dalam Microsoft Excel untuk diproses. Perisian SPSS telah digunakan untuk menganalisis data. Ujian analisis yang digunakan iaitu analisis data secara deskriptif seperti nilai peratus, min dan sisihan piawai. Jadual 1 di bawah menunjukkan interpretasi skor min yang digunakan kajian ini.

Jadual 1: Interpretasi Skor Min

\begin{tabular}{ll}
\hline Nilai Min & Interpretasi \\
\hline $4.01-5.00$ & Tinggi \\
$3.01-4.00$ & Sederhana Tinggi \\
$2.01-3.00$ & Sederhana Rendah \\
$1.00-2.00$ & Rendah \\
\hline
\end{tabular}

Sumber : Nunnally dan Bernstein (1994)

\section{Hasil Kajian}

\subsection{Demografi Responden Kajian}

Kajian ini telah melibatkan seramai 102 orang guru sekolah rendah di kawasan luar bandar di daerah Sri Aman, Sarawak. Berdasarkan pecahan jantina, majoriti guru yang menjawab borang soal selidik kajian ini adalah guru perempuan iaitu seramai 59 orang (57.8\%) berbanding dengan guru lelaki seramai 43 orang (42.2\%). Manakala dari segi julat umur pula, guru yang paling ramai adalah dalam lingkungan umur 41-50 tahun iaitu seramai 34 orang (33.3\%) diikuti lingkungan umur 31-40 tahun iaitu seramai 33 orang (32.4\%), lingkungan umur 51-60 tahun adalah seramai 24 orang (23.5\%) dan yang paling sedikit ialah lingkungan umur bawah 30 tahun iaitu seramai 11 orang (10.8\%). Seterusnya untuk tempoh pengalaman mengajar, kebanyakan guru yang mempunyai pengalaman mengajar lebih daripada 10 tahun adalah yang paling banyak iaitu seramai 72 orang (70.6\%), guru dengan pengalaman mengajar 6-10 tahun seramai 16 orang (15.7\%) dan guru dengan pengalaman mengajar bawah 6 tahun adalah yang sedikit iaitu 14 orang $(13.7 \%)$.

\subsection{Analisis Tahap Stres Responden}

Jadual 2 menunjukkan tahap stres guru berdasarkan jantina. Berdasarkan analisis deskriptif yang menunjukkan nilai min, sisihan beserta interpretasi tahap stres, menunjukkan tahap stres keseluruhan guru adalah tinggi. Namun didapati guru lelaki menunjukkan nilai min yang lebih tinggi $(\min =4.16$, s.p. $=0.58)$ berbanding guru perempuan $(\min =4.04$, s.p. $=0.61)$.

Jadual 2: Tahap Stres Guru Berdasarkan Jantina

\begin{tabular}{cccc}
\hline Jantina & Min & Sisihan Piawai & Interpretasi \\
\hline Lelaki & 4.16 & 0.58 & Tinggi \\
Perempuan & 4.04 & 0.61 & Tinggi \\
\hline
\end{tabular}


Jadual 3 menunjukkan tahap stres guru berdasarkan umur. Berdasarkan analisis deskriptif yang menunjukkan nilai min, sisihan beserta interpretasi tahap stres, menunjukkan tahap stres kebanyakan kumpulan julat umur guru adalah tinggi. Julat umur guru antara 51-60 tahun menunjukkan nilai min yang paling tinggi ( $\min =4.30$, s.p. $=0.55)$, diikuti julat umur 31-40 tahun ( $\min =4.06$, s.p. $=0.46)$, julat umur 41-50 tahun $(\min =4.05$, s.p. $=0.74)$ dan julat umur bawah 30 tahun menunjukkan nilai min yang rendah daripada keseluruhan julat umur $(\min =3.86$, s.p. $=0.56)$.

Jadual 3: Tahap Stres Guru Berdasarkan Umur

\begin{tabular}{llll}
\hline Umur & Min & Sisihan Piawai & Interpretasi \\
\hline Bawah 30 tahun & 3.86 & 0.56 & Sederhana Tinggi \\
31-40 tahun & 4.06 & 0.46 & Tinggi \\
41-50 tahun & 4.05 & 0.74 & Tinggi \\
51-60 tahun & 4.30 & 0.55 & Tinggi \\
\hline
\end{tabular}

Jadual 4 menunjukkan tahap stres guru berdasarkan umur. Berdasarkan analisis deskriptif yang menunjukkan nilai min, sisihan beserta interpretasi tahap stres, menunjukkan keseluruhan tahap stres berdasarkan pengalaman mengajar adalah sederhana tinggi. Guru yang mempunyai pengalaman mengajar lebih dari 10 tahun menunjukkan nilai min yang paling tinggi $(\min =4.15$, s.p. $=0.59)$, guru dengan pengalaman mengajar bawah 6 tahun berada dalam stres sederhana tinggi $(\mathrm{min}=3.95$, s.p. $=0.55$ ) dan guru dengan pengalaman mengajar 6-10 tahun juga dalam kategori stres sederhana tinggi $(\mathrm{min}=3.94$, s.p. $=0.68)$.

Jadual 4: Tahap Stres Guru Berdasarkan Pengalaman Mengajar

\begin{tabular}{llll}
\hline Pengalaman Mengajar & Min & Sisihan Piawai & Interpretasi \\
\hline Bawah 6 tahun & 3.95 & 0.55 & Sederhana Tinggi \\
6-10 tahun & 3.94 & 0.68 & Sederhana Tinggi \\
Lebih 10 tahun & 4.15 & 0.59 & Tinggi \\
\hline
\end{tabular}

\subsection{Analisis Strategi Daya Tindak Responden}

Jadual 5 menunjukkan strategi daya tindak yang digunakan oleh guru dalam mengurangkan stres sewaktu PdPR.

Jadual 5: Strategi Daya Tindak

\begin{tabular}{llll}
\hline Strategi Daya Tindak & Min & Sisihan Piawai & Interpretasi \\
\hline Skala Kesihatan & 2.19 & 0.62 & Sederhana Rendah \\
Skala Pemikiran & 2.04 & 0.43 & Sederhana Rendah \\
Skala Daya Tindak Aktif & 1.99 & 0.35 & Rendah \\
Skala Kemudahan Sosial & 2.06 & 0.41 & Sederhana Rendah \\
Skala Pengurangan Stres & 1.84 & 0.66 & Rendah \\
Skala Kerohanian & 1.49 & 0.61 & Rendah \\
\hline
\end{tabular}

Berdasarkan analisis deskriptif yang menunjukkan nilai min, sisihan beserta interpretasi strategi daya tindak dalam Jadual 5, didapati skala kesihatan menunjukkan nilai min sederhana rendah $(\min =2.19$, s.p. $=0.62)$ diikuti skala kemudahan sosial $(\min =2.06$, s.p. $=0.41)$ dan skala pemikiran $(\min =2.04$, s.p. $=0.43)$. Seterusnya didapati tiga strategi yang mendapat pilihan yang rendah iaitu skala daya tindak aktif $(\min =1.99$, s.p. $=0.35)$, 
skala pengurusan stres $(\min =1.84$, s.p. $=0.66)$ dan skala kerohanian $(\min =1.49$, s.p. $=$ 0.61).

\section{Perbincangan Kajian}

Memandangkan transformasi kerja guru yang semakin meluas dan bertambah semenjak pandemik Covid-19 ini, maka kajian ini memfokuskan kepada perubahan terkini dalam skop kerja guru, iaitu tahap stres guru dan strategi daya tindak guru luar bandar di Sarawak sewaktu PdPR. Berdasarkan dapatan kajian yang diperoleh, pengkaji mendapati bahawa responden kajian mengalami tahap stres yang tinggi. Apabila melihat aspek keguruan, stres yang dialami oleh guru didefinisikan sebagai pengalaman atau emosi yang tidak selesa berpunca daripada tugasan mengajar (Kyriacou, 2001). Lazarus dan Folkman (1984) pula berpendapat bahawa guru mengalami stres apabila mereka mendapati tugasan yang diberikan melebihi kemampuan mereka untuk menyelesaikannya. Ini juga selari dengan kajian Putwain dan von der Embse (2019) yang mendapati stres yang disebabkan oleh perubahan kurikulum juga berkait rapat dengan beban kerja guru dan efikasi kendiri mereka.

Stres yang dialami oleh guru sewaktu PdPR ini berkait rapat dengan kesediaan guru untuk mengendalikan kemahiran teknologi. Kajian oleh Yogeswary dan Helmi (2021) mendapati guru yang mempunyai pengalaman mengajar 1 hingga 20 tahun mempunyai kemahiran teknologi pada tahap yang tinggi jika dibandingkan dengan guru yang berpengalaman mengajar 21 tahun ke atas. Sepertimana dapatan kajian ini yang mendapati guru-guru yang mempunyai pengalaman mengajar 10 tahun ke atas didapati mengalami tahap stres yang tinggi ( $\min =4.15$ ). Guru yang mempunyai pengalaman mengajar yang lama lebih cenderung memilih kaedah pengajaran secara tradisional dan bersemuka dan tidak mudah untuk mengadaptasi perubahan sewaktu pelaksanaan PdPR. Menurut Shampa (2016) juga mendapati guru berasa takut dan sukar untuk belajar teknologi baharu. Maka seharusnya, guru harus mempunyai kesediaan menghadapi perubahan ke arah penggunaan teknologi terkini bagi menghasilkan proses PdPR yang lebih berkesan.

Dapatan kajian ini juga mendapati guru lelaki menunjukkan tahap stres yang lebih tinggi ( $\mathrm{min}=4.16)$. Ini berbeza dengan dapatan kajian oleh Michael et al. (2021) yang mengkaji tahap stres dalam kalangan guru di Filipina sewaktu Covid-19 mendapati guru perempuan lebih cenderung berhadapan dengan stres berbanding guru lelaki (min = 55.62). Kajian oleh Ozamiz-Etxebarria (2021) di Sepanyol juga mendapati guru perempuan menghadapi tahap stres yang tinggi $(\mathrm{min}=4.28)$ berbanding guru lelaki. Turut dilaporkan dalam kajian oleh Santamaria et al. (2021), guru perempuan di Sepanyol menunjukkan lebih banyak simptom stres dan keresahan berbanding guru lelaki iaitu sebanyak $15.8 \%$ guru perempuan berada dalam tahap stres sederhana berbanding dengan guru lelaki yang hanya mewakili $13.4 \%$.

Pelaksanaan PdPR lebih dilihat keberkesanan pelaksanaannya sewaktu mengendalikan atas talian. Namun hakikat bagi sekolah yang berada di luar bandar, akses kepada peranti dan talian internet adalah sangat terhad. Maka dalam situasi ini, kaedah pengajaran dalam talian bukanlah satu alternatif yang sesuai dalam pelaksanaan PdPR. Guru berdepan dengan stres apabila murid tidak dapat mengikuti sesi pembelajaran secara sepenuhnya dan berterusan akibat masalah ini. Sesi bimbingan dan pentaksiran tidak dapat dijalankan secara efektif dan telus. Menurut Yaumi (2018), hambatan daripada aspek akses internet, perangkat keras (hardware) dan perangkat lunak (software) serta pembiayaan belajar 
secara atas talian menjadi kekangan dalam memaksimakan sumber-sumber belajar secara dalam talian.

Seterusnya untuk perbincangan berkaitan dengan strategi daya tindak yang dipilih oleh guru-guru dalam mengendalikan stres. Strategi daya tindak merupakan gabungan kognitif dan tingkah laku seseorang dalam menyelesaikan masalah dan tekanan yang dihadapi (Lazarus \& Folkman, 1984). Terdapat 16 item bagi soal selidik untuk strategi daya tindak dalam kajian ini yang mengambil kira dimensi skala kesihatan, skala pemikiran, skala daya tindak aktif, skala kemudahan sosial, skala pengurangan stres dan skala kerohanian. Secara keseluruhannya, berdasarkan daripada dapatan kajian ini mendapati strategi daya tindak yang digunakan oleh guru dalam kajian ini masih lagi berada tahap yang rendah. Ini menunjukkan guru tidak terdedah ataupun mempunyai kesedaran dalam pemilihan strategi daya tindak yang bersesuaian dalam mengendalikan stres mereka sewaktu pelaksanaan PdPR.

Skala Kesihatan, Skala Kemudahan Sosial dan Skala Pemikiran menjadi pilihan bagi strategi daya tindak responden kajian ini walaupun berada pada tahap sederhana rendah. Skala kesihatan melihat kepada bagaimana responden terlibat dengan gaya hidup aktif dalam pengurusan stres seperti bersenam, rehat yang mencukupi dan bertenaga dalam melakukan aktiviti seharian. Skala Kemudahan Sosial pula item yang berkaitan bagaimana interaksi sosial responden apabila berhadapan dengan orang sekeliling saat berada dalam situasi yang tidak menyenangkan. Skala Pemikiran pula melihat bagaimana responden berfikir dan membuat keputusan dalam situasi yang menekan.

Seterusnya diikuti dengan Skala Daya Tindak Aktif, Skala Pengurangan Stres dan Skala Kerohanian merupakan pilihan yang kurang dipilih oleh responden dalam pemilihan strategi daya tindak dalam menangani stres. Skala Daya Tindak Aktif menilai apakah tindakan yang diambil oleh responden apabila berhadapan dengan situasi yang menekan. Manakala Skala Pengurangan Stres melihat bagaimana responden mempunyai kesedaran dan mengamalkan cara bertenang apabila menghadapi stres. Akhir sekali bagi Skala Kerohanian, adalah item yang menilai bagaimana responden melihat cara kerohanian dan matlamat hidup sebagai satu cara menangani stres dengan berkesan.

Maka, melalui pemilihan strategi daya tindak yang bersesuaian dalam menangani stres sekaligus akan meningkatkan tahap kesejahteraan psikologi guru untuk berkhidmat dengan lebih cemerlang, mencapai tahap kepuasan kerja dan menunjukkan prestasi kerja yang optimum sekaligus mampu beradaptasi dengan cabaran dan transformasi pendidikan negara. Dapatan kajian Ienats dan Titin (2017) terhadap guru-guru di Indonesia mendapati melalui pemilihan daya tindak yang betul ketika menghadapi tekanan boleh meningkatkan kesejahteraan psikologi guru. Manakala kajian Jiang et al. (2017) menunjukkan pemilihan strategi daya tindak yang positif seperti strategi berfokuskan masalah berperanan untuk mengurangkan tekanan kerja guru berbanding dengan pemilihan strategi daya tindak negatif seperti berfokuskan emosi akan menambahkan lagi tekanan kepada guru.

Pada masa yang sama, guru yang memilih strategi yang positif secara tidak langsung akan meningkatkan efikasi diri mereka. Ini berlaku apabila guru yang memilih strategi positif akan memilih pendekatan berhadapan dengan masalah dan menyelesaikan masalah tersebut. Guru ini mempunyai keyakinan diri yang tinggi berhadapan dengan masalah dalam pekerjaan mereka berbanding dengan guru yang memilih strategi daya tindak yang negatif. Pemilihan strategi daya tindak negatif pula seperti penghindaran dan isolasi 
adalah situasi di mana guru melarikan diri daripada masalah yang dihadapi. Tindakan ini hanya membuatkan emosi guru hanya dapat dilegakan dalam tempoh masa yang singkat, namun kitaran masalah yang tidak diselesaikan hanya akan membuatkan mereka berterusan mengalami tekanan kerja yang akhirnya membawa kepada burnout. Kenyataan ini disokong melalui kajian oleh Cappe et al. (2021) yang melibatkan guru yang mengajar murid autisme di Perancis dan Quebec di mana guru yang memilih strategi memfokuskan masalah dilaporkan mempunyai risiko burnout yang rendah dan efikasi kendiri yang tinggi dan sebaliknya bagi guru yang memilih strategi memfokuskan kepada emosi.

\section{Kesimpulan}

Kesimpulannya, guru akan sentiasa berhadapan dengan perubahan sistem dan dasar pendidikan negara. Tuntutan perubahan ini adalah perlu dalam mempersiapkan generasi muda dalam berhadapan dengan tuntutan pekerjaan dan kehidupan masa depan di mana guru adalah penyampai dan pemudahcara utama kepada ilmu serta kemahiran itu. Setiap pekerjaan pastinya mempunyai cabaran dan stres tersendiri. Maka guru hendaklah bijak dalam mengenal pasti tahap stres dan strategi daya tindak yang harus diambil agar dapat memberikan kesan yang positif kepada mereka dalam menghadapi tekanan pekerjaan, sekaligus meningkatkan kesejahteraan dan kualiti kerja guru.

\section{Penghargaan (Acknowledgement)}

Terima kasih diucapkan kepada pensyarah-pensyarah pembimbing saya iaitu Dr Ruslin Amir dan Dr Salleh Amat dan juga kepada kesemua responden yang terlibat dalam kajian ini.

\section{Kewangan (Funding)}

Kajian dan penerbitan ini tidak menerima sebarang tajaan atau bantuan kewangan.

\section{Konflik Kepentingan (Conflict of Interests)}

Penulis tidak mempunyai sebarang kepentingan dalam kajian ini.

\section{Rujukan}

Amri, A., Abidli, Z., Elhamzaoui, M., Bouzaboul, M., Rabea, Z., \& Ahami, A. O. T. (2020). Assessment of burnout among primary teachers in confinement during the COVID19 period in Morocco: case of the Kenitra. The Pan African medical journal, 35(Suppl 2).

Cappe, E., Poirier, N., Engelberg, A., \& Boujut, E. (2021). Comparison of teachers in France and in Quebec working with autistic students: Self-efficacy, stress, social support, coping, and burnout. Teaching and Teacher Education, 98, 103244.

Iftakhar, S. (2016). Google classroom: what works and how. Journal of Education and Social Sciences, 3(1), 12-18.

Izazol Idris. (2019). Pengaruh Resiliensi, Daya Tindak, Dan Kecerdasan Menghadapi Cabaran Terhadap Kesejahteraan Psikologi Dalam Kalangan Pelajar Universiti (Doctoral dissertation, Universiti Sains Malaysia). 
Jiang, X. R., Du, J. J., \& Dong, R. Y. (2017). Coping style, job burnout and mental health of university teachers of the millennial generation. Eurasia Journal of Mathematics, Science and Technology Education, 13(7), 3379-3392.

Kementerian Pendidikan Malaysia (2021). Manual Pengajaran dan Pembelajaran di Rumah Versi 2. Kementerian Pendidikan Malaysia. Retrieved from https://www.moe.gov.my/pekeliling/4081-manual-pengajaran-danpembelajaran-versi-2-2-feb-2021-1/file

Kyriacou, C. (2001). Teacher stress: Directions for future research. Educational review, 53(1), 27-35.

Lazarus, R. S. (1993). From psychological stress to the emotions: A history of changing outlooks. Annual review of psychology, 44(1), 1-22.

Lazarus, R. S., \& Folkman, S. (1984). Stress, appraisal, and coping. Springer publishing company.

MacIntyre, P. D., Gregersen, T., \& Mercer, S. (2020). Language teachers' coping strategies during the Covid-19 conversion to online teaching: Correlations with stress, wellbeing and negative emotions. System, 94, 102352.

Medline Medical Encylopedia. (2020). Stres and your health. Retreived from https://medlineplus.gov/ency/article/003211.htm

Mohamad Saiful Samsudin \& Wan Shahrazad Wan Sulaiman. (2020). Hubungan Antara Tingkah Laku Interpersonal Guru, Kepuasan Kerja dan Kecenderungan Burnout Guru-Guru Tingkatan Enam di Perlis. Jurnal Wacana Sarjana, 4(1), 1-9.

Mohd Majid Konting. (1990). Kaedah penyelidikan pendidikan. Dewan Bahasa dan Pustaka.

Nunnally, J. \& Bernstein, I. (1994). Psychometric Theory ( $3^{\text {rd }}$ ed.). New York. McGraw-Hill.

Ozamiz-Etxebarria, N. (2021). Emotional state of school and university teachers in northern Spain in the face of COVID-19. Revista espanola de salud publica, 95.

Pelan Induk Pembangunan Pendidikan. (2013). Retrieved from https://www.moe.gov.my/muat-turun/penerbitan-dan-jurnal/1818-pelanpembangunan-pendidikan-2013-2025/file

Putwain, D. W., \& von der Embse, N. P. (2019). Teacher self-efficacy moderates the relations between imposed pressure from imposed curriculum changes and teacher stress. Educational Psychology, 39(1), 51-64.

Santamaria, D. M., Idoiaga Mondragon, N., Berasategi Santxo, N., \& Ozamiz-Etxebarria, N. (2021). Teacher stress, anxiety and depression at the beginning of the academic year during the COVID-19 pandemic. Global Mental Health, 8.

Sokal, L. J., Eblie Trudel, L. G., \& Babb, J. C. (2020). Supporting teachers in times of change: The job demands-resources model and teacher burnout during the COVID-19 pandemic.

Yaumi, M. (2018). Penerapan Model Assure dalam Pengembangan Media dan Teknologi Pembelajaran PAI. 